\title{
The Role of Wayang Golek as Prototype Model in Building Mega skill Characters of Children
}

\author{
Leli Halimah, Robandi Roni, Margaretha Sri Yuliariatiningsih, Ai Sutini \\ Early Childhood Education Study Program (PGPAUD), Universitas Pendidikan Indonesia, Kampus Cibiru
}

Corresponding e-mail: lelihalimah@upi.edu

\begin{abstract}
The Purpose of this study is to develop learning model prototype of building children's mega skill characters through creative-integrated curriculum in kindergarten. The media which is used in this study is wayang golek (Sundanese traditional puppets). This study is a preliminary study which is part of three research stages in research and development method. The data gathered authentically which inspires in developing model prototype based on the element of West Java traditional culture by using creative and integrative wayang golek characters. The result of the study shows that the using of wayang golek characters can give an inspiration to the children. Moreover, it gives an impact in increasing children's mega skills character. This learning model prototype hopefully can be the fundamental basis to produce the qualified learning model in developing mega skill characters in early age.
\end{abstract}

Keywords: developing mega skill characters, wayang golek, early childhood education curriculum

\section{INTRODUCTION}

The civilization of one country depends on the quality of early childhood education (ECE). Children will become valuable infestations of high quality human resources if adult (parents and teachers) afford to build their characters in early years. According to Ferdiawan \& Putra (2003) that early childhood education is one of the factors that affect the quality of human resources. Moreover, in this digital era, character education is indeed a high priority (McElmeel, 2002). "Character is the foundation to all our relationships: working, learning, loving, community, and more" (Dimerman, 2009). In this case, character education has strong related to curriculum, since curriculum is the heart of education (Null, 2011). One of the character aspects that are needed to be developed is mega skills character. It is important to conceptualize it into curriculum creatively and interactively.

Indonesia as one of developing country since beginning has proposed character education as one of education program. Along with globalization era, Indonesian government try hard in improving quality of human resources by launch a program:
"Character education grand design of 2045 gold generation" (Rokhman, et al., 2014). This program started by compile better curriculum based on some philosophical values, namely: 1) education base on nation's culture to develop national life in the present and future time. This view makes 2013 Indonesian ECE curriculum is developed based on cultural diversity of Indonesian by Bhineka Tunggal Ika principals. 2) Creative children are the heir of nation's culture. This philosophical view proposes that national achievement in every field should be contended in the curriculum in order to inspire the children (Permendikbud Nomor 146 tahun 2014). These two philosophical bases give signs that curriculum development should be contextual and implementing cultural values approaches (Ferdiawan $\&$ Putra, 2013). Moreover, since children are generation of creative national culture. Moreover, national achievement in the past should be included in the content of curriculum to give inspiration and pride to the children (Permendikbud, 2014: Ferdiawan \& Putra, 2013). This means that teachers of early childhood education should be able to implement those philosophical values in preparing 
the children to have skills and learning experiences to be success in their future (Trilling \& Fadel, 2009).

According to the explanation above, the problem is how the curriculum implementation continuity either in school level or in the class level is? From this problem, this article explains the result of the preliminary study that is done in West Java, which has wayang golek traditional culture. It is played by a person called dalang. Commonly, Wayang golek performance presents moral messages and character values in their stories to the audiences. For example the story that tells about loyalty, honor, and returning the favours. Indeed wayang golek has some characters that become role model for the societies (Nurgiyantoro, 2011; Kompasiania, 2011). Wayang golek is interesting for the children because its similarity with the puppet toys. Therefore, it is assumed that wayang golek can be as learning media in developing children's characters (Irfansyah, 2010). Its purpose is to describe sustainable of continuity policy and model prototype of building mega skills character in creative and integrative preschool curriculum using wayang golek character.

\section{LITERATURE REVIEW}

\subsection{Character Values in Early Childhood Education Curriculum}

The launching of Grand design of education character of gold generation 2045, aims to prepare the generation in the future to have positive attitude, essential thinking skill, normative commitment, and ability based on IESQ (intellectual quotient, emotional quotients -EQ and spiritual quotient) (Manullang,2013; Rokhman, et all, 2014; kemendiknas, 2010). Based on the grand design of education character, Kemendikas $(2010 ; 2011)$ has put the priority on character values which is very important to be internalized to the children. There are 18 character values. The follow up is put explicitly in Indonesian preschool curriculum. There are 4 main competence (KI) which it consists KI-1; spiritual attitude, KI-2; social attitude, KI-3; knowledge, KI-4; skill. Those KI are the description of children's development standard from 0 to 6 years old.

The character values in KI, basically is the same with character the values according to Rich (2008) which is called mega skills. It is really urgent that the children should have those skills in early age. Those skills consist of 12 characters values, namely; confidence, motivation, hard work, responsible, initiative, eager to learn, care, cooperative, good thinking skill, problem solving, focus, respect. All those character values are as important as study achievements, since to be success is not only success academically, to achieve score A from the test, but also to achieve score $\mathrm{A}$ in a real life. Moreover, there are so many character values that are very important have to be taught in early age, as Almerico (2014) stated according to the recommendation from the character education expert, there are 11 character values. In addition, Mather and Weldon arranged alphabetically 36 character values and Stevenson (2006)

alphabetically about 50 character values.

Normally, character is described as someone's attitude or personality that is formed from the result of internalization of many virtues that is believed and used as fundamental to the way of thinking, viewing, behaving, and acting (Kemendiknas, 2010; Aziz, 2011; Arthur 2003; Livo 2003; Nurgiyantoro, 2011). Therefore, the person who has good character means he/she has good moral knowledge, has good moral feeling, and always do the good action. All of them have impact each other (Lickona, 2006). The person who has good character is the person who is able to act based on good thinking skill. In other words, character is the way of feeling, the way of tasting (Kemendiknas 2010). It means that education has to be formation of characters (Klann, 2007; Aziz, 2011; Rokhman and Yuliati, 2013).

Mega skills are the core of character values which become leverage for someone to love learning and become success in academic and in real life (Rich, 2008). Those values are also important to be developed in early childhood.

\subsection{Wayang Golek and Character Building in Early Childhood Education}

In some areas in Indonesia, they have traditional culture of wayang show, which is traditional puppet show. They have been noticed internationally as Indonesian's culture. This culture has many character values that give big impact in building and developing nation's character. There are some kinds of wayang such as: wayang kulit purwa from central Java, wayang parwa from Bali, wayang Palembang from South Sumatra, wayan Banjar from South Kalimantan and wayang golek from West Java. All of these kinds of wayang have been recognized by UNESCO as the world's great creation (Nurgiyantoro, 2011).

Wayang golek as one of the traditional culture from West Java is dolls of wood and shaped humanlike (Wikipedia 2016). At show art, wayang golek is led by a person called dalang. Besides plays 
wayang golek, he is also as a dubber of wayang golek which plays some characters on the show. In the last decades, when majority of Sundanese people did not have TV as main media of information and entertainment, wayang golek is one of the most important media of entertainment that effected people at that time. Every show of wayang golek gave moral messages or character values education for the audience, such as about loyalty, honor, and returning the favour. Therefore, the function of wayang golek had high position among the society (Sebandung. com; 2016). Besides, as entertainment, wayang golek had also the function as a media of broadcast and education, either it was about moral, rules, customs, or religion (Nurgiyantoro, 2011; Suyanto, 2010). Wayang golek usually played based on story that had many characters as follows: Arjuna, Gatot Kaca, Semar, Bima, Cepot, Dawala, Gareng, etc. (Hadi, 2015). In every story of wayang golek, every character had special character, especially a good character. Normally, it was used by the people to be role models for the children in understanding the character values (Nurgiyantoro, 2011).

Unfortunately nowadays, wayang golek is being unpopular, especially for the children. It is only played in special occasion with the majority of audience are old people. Even though, it is assumed as effective media of education and entertainment. Therefore, wayang golek should be introduced to the youth generation, including children. Not only have to conserve it as national culture, but also can be used as interesting media for the children in developing early childhood education curriculum.

\section{METHODOLOGY}

This study is on-going research that employs research and development approach (McMillan \& Schumacher, 2001; Singh, 2006; Ali, 2010; Sugiono 2014) that is designed for 3 years research implementation. This article is the result of research in the first year. Data collection is done through: document analysis study, participative observation, questioners, and interview. The location of the study is in West Java and its subject is public and private kindergartens. The test of the model prototype as pre experimental design that is done with one-shot case study: $(\mathrm{X}-0=\mathrm{X}$ treatment of independent variable 0 observation of dependent variable) at TK Laboratorium UPI Kampus Cibiru, Bandung, West Java.

\section{RESULT AND DISCUSSION}

\subsection{Developing Learning Model Prototype of Building Mega Skill Characters}

\subsubsection{Preschool Curriculum Documents}

Analysis of curriculum document based on pemendikbud number 1462014 explains that every school has to develop school curriculum (KTSP) based on national curriculum. KTSP document that is created by every education levels, consist of two documents. Document 1 consists of vision, mission, purpose of level of education, lesson, the setting of studying time, and education calendar. While document 2 consists of semester program, weekly lesson plan, and daily lesson plan.

The two of those documents, commonly use at the school that become the subject of this study. According to the standard, every school has document 1 that is already suitable with the standard, but if it is related to grand design of Indonesian education character, it has not been yet explicitly established the character values. It is more focused on using of mother tongue and using traditional customs through the program of "Rebo Nyunda". From the whole of those documents, traditional culture of wayang golek has not been a part of that curriculum document.

Together with the condition of document 1 , therefore in document 2 , the development of the character values generally has not been focused. In daily lesson plan for example, the teacher only noted (4-7) character values that should be achieved by the children in one learning process. Traditional culture of wayang golek, has not been a part of that document as a media or as a content of learning process and as an inspiration resources. Playing activities normally is designed for indoor playing activity.

Analysis result of that document gives the idea to design prototype learning model of building mega skill characters in developing preschool curriculum using creative-integrative wayang golek character. It is as the reference for the teacher in curriculum development. Prototype of learning model that is explained in this article is formed on daily lesson plan documents. They are designed creative and integrative by following the step of developing education character based on Kemendiknas (2010). In addition, they are adapted with the content of national curriculum. Prototype of learning model is as it is explained in this table below. 
Table 1. Learning Model Prototype of Daily Lesson Plan

\begin{tabular}{|c|c|c|}
\hline $\begin{array}{c}\text { Learning Steps } \\
\text { Activities }\end{array}$ & Evaluation & Resources \\
\hline $\begin{array}{l}\text { Pre activity: Circle time } \\
\text { - Praying } \\
\text { - Giving information about } \\
\text { theme/sub theme } \\
\text { - Story telling: focus on } \\
\text { character value } \\
\text { - Speaking: focus on the } \\
\text { character based on the } \\
\text { content of the story }\end{array}$ & $\begin{array}{l}\text { - Observation } \\
\text { - Anecdotes }\end{array}$ & $\begin{array}{l}\text { - Story text } \\
\text { - Wayang } \\
\text { Golek }\end{array}$ \\
\hline $\begin{array}{l}\text { Main activity: Choice time } \\
\text { (Actualization about moral } \\
\text { action) } \\
\text { Indoor activities : } \\
\text { - playing activity in } \\
\text { centre/area/corner } \\
\text { Outdoor activities: } \\
\text { - playing activity in } \\
\text { centre/area/corner }\end{array}$ & $\begin{array}{l}\text { - Observation } \\
\text { - Anecdotes }\end{array}$ & $\begin{array}{l}\text { Wayang } \\
\text { Golek } \\
\text { Characters } \\
\text { Base on } \\
\text { playing } \\
\text { activity }\end{array}$ \\
\hline Break time: Eating together & $\begin{array}{l}\text { - Observation } \\
\text { - Anecdotes }\end{array}$ & \\
\hline $\begin{array}{l}\text { Closing activity: Circle } \\
\text { time } \\
\text { Telling story of children's } \\
\text { playing experiences } \\
\text { Showing children's } \\
\text { products made from } \\
\text { playing activity } \\
\text { Reflection: playing activity } \\
\text { until they can create the } \\
\text { product } \\
\text { Sharing: child experience } \\
\text { related to the wayang golek } \\
\text { characters } \\
\text { Moral message for activity } \\
\text { with parents at home } \\
\text { Praying before going home }\end{array}$ & $\begin{array}{l}\text { - Observation } \\
\text { - Anecdotes } \\
\text { - Portfolios }\end{array}$ & $\begin{array}{l}\text { - Wayang } \\
\text { Golek } \\
\text { characters } \\
\text { - Art and } \\
\text { craft (art } \\
\text { product) }\end{array}$ \\
\hline
\end{tabular}

\subsubsection{Application of Learning Model Prototype of Building Mega Skill Characters}

Wayang golek characters were used by the teacher creatively in some stories that have character values. Because there are a lot of wayang golek characters, therefore, ones that were used in this study were selected according to character values that were developed to children. Wayang golek characters that were selected in this study are Gatot Kaca, Semar and Cepot. The teachers made story creatively and relate to character values and wayang golek characters, for example the story entitled
"Responsible Gatot Kaca”, “Confident Cepot”, "Gatot Kaca and Cepot work together in making block tower", and "Working hard Semar". In addition, the teachers used wayang golek characters that act out as the character who told the story. By using fable, child story or child literature, Gatot Kaca (dubbing by teachers) told story about "Brave Elephant", Cepot told story about "Arrogant Monkey" and Semar told story about "Story of the Mouse Family". After the teachers told story and discussed the character values, then the children were asked to play at outdoor or indoor areas. This was done to challenge the children to act the characters values that have been represented by wayang golek.

\subsubsection{Result of the Observation of Prototype Learning Model Implementation in Building Mega Skill Characters}

The table below describes each character values which have been developed for 12 weeks. Each character was developed in 4 days (code T1, T2, T3, T4). There are 4 scales of indicator, which are: 1 (BT): not yet seen, 2 (MT): start to be seen, 3 (MB): start to develop and 4 (SM) already familiarized. The data presented was only cumulative amount of the children who have reach indicator 4 . The data of effectiveness of the prototype learning model can be seen in this table.

Table 2. Character Values of Children

\begin{tabular}{l|llll}
\hline \multicolumn{1}{c}{$\begin{array}{c}\text { Mega skill } \\
\text { Character values }\end{array}$} & T1 & T2 & T3 & T4 \\
\hline Confident & 3 & 5 & 7 & 8 \\
\hline Motivation & 4 & 5 & 6 & 7 \\
\hline Effort & 5 & 8 & 8 & 10 \\
\hline Responsibility & 4 & 6 & 8 & 9 \\
\hline \begin{tabular}{l|l|l|l|} 
Initiative \\
Hard willing
\end{tabular} & 2 & 3 & 6 & 8 \\
\hline $\begin{array}{l}\text { Love } \\
\text { Cooperative }\end{array}$ & 5 & 8 & 9 & 10 \\
\hline $\begin{array}{l}\text { Logic } \\
\text { thinking }\end{array}$ & 1 & 6 & 8 & 10 \\
\hline $\begin{array}{l}\text { Problem } \\
\text { solving }\end{array}$ & 2 & 6 & 8 & 11 \\
\hline $\begin{array}{l}\text { Concentration } \\
\text { Respect }\end{array}$ & 6 & 8 & 7 & 8 \\
\hline & 6 & 8 & 5 & 6 \\
\hline
\end{tabular}




\subsection{Discussions}

Education character will be effective when it is explicitly the character values belong to the children are integrated in curriculum developing program and it should be done through discussing among the principal, teacher, school, staff and with parents (Rich 2008). Especially in its implementing, the teacher professionally should find conducive ways in developing every child's characters (Stallon\& Yeats, 2003; Almerico 2014: Winarni; 2013).

Related to the developing learning model of building mega skill character, it is not only character values that is stated in the curriculum explicitly, but also media development that consider effective to be role model for the children. Therefore, traditional culture wayang golek, as the character in west Java is used in this study, since it is recognized not only has entertainment content but also has the moral messages that can educate the people. This has correlation with the statement of Almerico (2014) that the traditional culture can be formed in a story that is fixed with the children world, so it can create the qualified children literature products. Literature is effective learning tool in building child's character (Bohlin, 2005; Sheldon, 2004). Therefore, wayang golek character can be created in children's story or as a character that told the story. Moreover, the children will be interested to wayang golek because wayang golek is including into the category of doll. In addition, according to Irfansyah (2010) it is suitable to be used as media and inspiration resources in teaching character values to the children as long as learning.

McElmeel (2002) stated the simple way in teaching character values to the children, can start every day in early activity with providing the time around 15 minutes to 20 minutes, when the children are in the circle time. The teacher reads the story in front of the children about the character, focused on one special character. After that, ask the children to talk about the character. Then, ask the children to make relationship to their behavior and try to find the chance to present and develop character as the actor in the story.

Letting the children to listen the story in a long time is not suggested, considering it is better for the children to learn through playing. Therefore, in this learning model prototype, after the teacher tells the story, the teacher should be professionally facilitating the children to play outdoor or indoor. This is because they are still in playing world. Through playing, the children will learn many things about their environment (Curtis, 2002; Smith, 2010;
Whitebread \&Coltman 2008; Gordon \&Browne, 2011: Jackman, 2012). Moreover, playing is a powerful vehicle for learning (Sher 2004). So, teaching character values to preschool children ideally through playing. Ragsdale \& Saylor, (2009) stated that the innovation that gives the contribution to the child's character complement is through creative playing activity.

White (2008); Fjortoft (2001) stated that, normally the favorite place for playing is outdoor. Playing outdoor is more effective as learning strategy in stimulating children's development aspects and character values. According to Bilton (2010) outdoor area is a complete playing environment, which provides all the children needs, either the needs for the cognitive, linguistic, emotional, social or physic developing. So, the experience from outdoor activity is important component that can integrate head, heart and hand (Day \&Midbjer 2007; Moyles 2007; White, 2008). Outdoor is dynamic environment which always has change, while indoor is different environment than outdoor.

White (2008); Aslan, (2011) stated that outdoor offers perfect assistant to provide the thing that the children can't get from indoor activity. From that situation, in this learning model prototype, the teacher should consistently, facilitate the children to play outdoor or indoor in thematic context, to challenge the children to do the moral action as the good wayang golek character in the story. To help the children in order they can be a good moral person.

The result of this research has proved that wayang golek as a cultural heritage is very attract the children interest. Based on the story of wayang, there is a goddess's value and heroic value which is good to become role model in teaching character to the children (Kompasiania, 2011). That should be noticed is how wayang golek can be hero character.one of them is, the teacher ideally should be competence in telling story, "teacher as story teller" (Jackman, 2012) with using many child's literature (Almerico, 2014) that is modified creatively. Arthur (2003) stated that every teacher has to be able to teach character to the children, and be a role model for the children (Miller (2009); Squido (2012); Kemendikbud (2013). Actually, that should be noticed that in teaching character values to the children: commitment to children's development; stimulation of creativity and critical thinking; provision for different learning modalities; practice for working cooperatively; consistency of format (Rich, 2008). This principle basically is the 
way that should be followed up by a preschool teacher in teaching mega skill character values to children in early age.

\section{CONCLUSIONS}

Learning model prototype of building mega skill character in preschool curriculum using wayang golek character, as the result of this preliminary study is assumed can be one of alternative way to increase the quality of early human resources, especially in West Java area. It should be enter into grand design of character education and philosophy fundamental of curriculum development. Implementation of learning model prototype of building mega skill character, through presenting creative and integrative wayang golek in developing education preschool curriculum, has effectively attract the children that give the impact to the amount of the children in achieving mega skill character building. The implication is every wayang golek character in the story focused on the character will be able to represent every wayang character that becomes a hero for early age children. The teacher competently should be able to create wayang golek in curriculum document and in learning process creatively-integrative.

\section{ACKNOWLEDGEMENTS}

Thank you very much especially to Kemenristek dikti that has given the fund in this research through the national strategy research grant. The result of this research is just the preliminary study step before this model is followed up on limited test and further test.

\section{REFERENCES}

Ali, M. (2010). Metodologi dan Aplikasi: Riset Pendidikan. Bandung: Pustaka Cendekia Utama.

Almerico, G. M. (2014). Building character through literacy with children's literature. Research in Higher Education Journal Volume 26 pp. 113

Arthur, J. (2003). Education with character: The moral economy of schooling. London: RoutledgeFalmer Taylor and Francis Group

Aslan, M. (2011). Handbook of Moral and Character Education, Edt. Larry P. Nucci and Darcia Narvaez. International Journal of Instruction. Vol.4, No.2; 4 (2011 - 2014).
Aziz. H. A. (2011). Pendidikan karakter berpusat pada hati: Akhlak mulia pondasi Membangun karakter bangsa. Jakarta: AlMawardi Prima.

Bilton, H. (2010). Outdoor learning in the early years: Management and innovation. New York: RoutledgeTaylor\& Francis Group.

Bohlin, K. E. (2005). Teaching character education through literature: Awakening the moral imagination in secondary classrooms. London: RoutledgeFalmer Taylor \& Francis

Curtis, A. (2002). A Curriculum for the pre-school child: Learning to learn. London: Routledge.

Day, C., \&Midbjer, A. (2007).Environment and children: Passive lessons from the everyday environment. Amesterdam: Elsevier.

Dimerman, S. (2009). Character is the key: How to unlock the best in our children and ourselves. Canada: John Wiley \& Sons Canada, Ltd.

Ferdiawan, E., \& Putra, W.E. (2013). Esq education for children character building based on philosophy of Javanese in Indonesia. Procedia - Social and Behavioral Sciences. 106, 7(1096 - 1102).Published by Elsevier Ltd; doi: 10.1016/j.sbspro.2014.05.197

Fjørtoft, I. (2001). The natural environment as a playground for children: The impact of outdoor play activities in pre-primary school children. Early Childhood Education Journal, Vol. 29, No. 2: 7 (111-117).

Gordon, A. M. \& Browne, K. W. (2011).Beginnings and beyond: Foundations in early childhood education. Australia: Wadsworth, Cengage Learning

Hadi, S. (2015). Karya seni: Mengenal lebih dekat wayang golek, kesenian asli jawa barat yang begitu mempesona. (Online). http://www.satujam.com/wayang-golek/

Howard, R.W., Berkowitz, M. W. \& Schaeffer, E. F. (2004).Politics of Character Education. Educational Policy, Vol. 18 No.1, January and March 2004. Published by: http://www.sagepublications.com

Irfansyah, D.T. (2010) Karakter game berbasis tokoh raut golek Sunda. Wimba: (Online) Jurnal Komunikasi Visual \& Multimedia. Volume 1 Nomor 1: 15 (41-55).

Jackman, H. L. (2012).Early education curriculum: A child's connection to the world. United States of America: Wadsworth, Cengage Learning.

Kemendiknas. (2010). Kerangka acuan Pendidikan karakter. Jakarta: Kemendiknas; Direktorat 
Ketenagaan; Direktorat Jenderal Pendidikan Tinggi; Kemetrian Pendidikan Nasional.

Kemdiknas. (2011). Pendidikan karakter untuk membangun karakter bangsa. Jakarta: Direktorat Jenderal Pendidikan Dasar, Kemdiknas.

Kemendikbud. (2013).Petunjuk Teknis Pengajuan, Penyaluran, dan Pengelolaan Bantuan Pendidikan Karakter melalui Satuan Pendidikan Nonformal. Jakarta: Kemendikbud, Direktorat Jenderal PAUD, Nonformal dan Informal, Direktorat Pembinaan Pendidikan Masyarakat.

Klann, G. (2007). Building character: Strengthening the heart of good leadership. United States of America: John Wiley \& Sons, Inc.

Kompasiania. (2011). Wayang, media Pendidikan karakter bangsa. (Online) (http://www.kompasiana.com/benitoramio/way ang-media-pendidik-karakterbangsa_550ad94a813311490eb1e6f5)

Lickona (2006).Educating for character. New York: Bantam Book.

Livo, N. J. (2003). Bringing Out Their Best: Values Education and Character Development Through Traditional Tales. United States of America: A Division of Greenwood Publishing Group, Inc.

Manullang, B. (2013). Grand desain Pendidikan karakter generasi emas 2045.JurnalPendidikanKarakter, Tahun III, Nomor 1, 14 (1-14).

Mather, Anne D. \& Weldon, Louise B. (2006). Character building day by day: 180 quick read-alouds for elementary school and home. United States of America: Free Spirit Publishing (eBook ISBN: 978-1-57542-876-5)

McElmeel, S. L. (2002). Character education: $a$ book guide for teachers, librarians, and parents. United States of America: A Division of Greenwood Publishing Group, Inc. McMillan, J.H. \& Schumacher, S. (2001).Research in education. New York: Longman.

Moyles, J. (2007). (Ed). Early year's foundations: Meeting the challenge. England McGraw-Hill Open University Press.

Novick, B. Kress, J. S. \& Elias, M. J. (2002).Building learning communities with character: how to integrate academic, social, and emotional learning. United States of America: Association for Supervision and Curriculum Development (ASCD).
Null, W. (2011). Curriculum: From theory to practice. United States of America: Roman\& Littlefield Publishers, Inc.

Nurgiyantoro, B. (2011). Wayang dan pengembangan karakter bangsa. (Online) Jurnal Pendidikan Karakter, Tahun I, Nomor 1: 17 (18-34).

Permendikbud nomor 146 tahun 2014. Tentang Kurikulum 2013 pendidikan anak usia dini. Jakarta; Depdikbud.

Rich, D. (2008). Mega Skills: Building our children's character and achievement for school and life. Naperville, Illinois: Sourcebooks, Inc.

Rokhman, F., Hum, M., Syaifudin, A. \&Yuliati. (2014). Character education for golden generation 2045 (national character building for Indonesian golden years). Procedia Social and Behavioral Sciences. 141, 5(1161 1165).Published by Elsevier Ltd; doi: 10.1016/j.sbspro.2014.05.197

Sugiyono. (2014). Metode penelitian pendidikan: Pendekatan kuantitatif, kualitatif, dan $R \& D$. Bandung: Alfabeta.

Sayanto. (2010). Seni pertunjukkan wayang sebagai wahana pendidikan. (Online): (http://suyanto.dosen.isi-ka.ac.id/2010/12/).

Sebandung, Com. (2016). Keunikan wayang golek, seni tradisional khas sunda. (Online). https://sebandung.com/2014/02/senitradisional-khas-sunda/

Sheldon, L. (2004). Character development and storytelling for games. United States of America: Thomson Course Technology PTR

Sher, B. (2004).Smart play: 101 fun, easy games that enhance intelligence. Canada: John Wiley \& Sons, Inc.

Singh, Y.K. (2006). Fundamental of research methodology and statistics. New Delhi: New Age International (P) Ltd., Publishers.

Smith, P. K. (2010). Children and Play. United Kingdom: Wiley-Blackwell Publishing.

Stallions, M. A. \& Yeatts, K. (2003).Enhancing character education for tomorrow's teacher, today: A connected learning partnership model. Florida Association of Teacher Educators Journal. Volume 1 Number 3; 11(250-260).

Stevenson, N. (2006). Young person's character education handbook. United States of America: JIST Publishing, Inc.

Squidoo. (2012) Children: Building character. (Online). http://www.squidoo.com/MiMi 
Tovey, H. (2007). Playing outdoors: Spaces and places, risk and challenge. England: McGrawHill Education Open University Press Wikipedia. (2016). Wayang golek. (Online). https://id.wikipedia.org/wiki/Wayang_golek

Winarni.S. (2013).Integrasi pendidikan karakter dalam perkuliahan. Jurnal Pendidikan Karakter, Tahun III, Nomor 1; 42 (95-136).

White, J. (2008). Playing and learning outdoors: Making provision for high-quality experiences in the outdoor environment. London: Routledge Taylor \& Francis Group.

Whitebread, D., \&Coltman, P. (2008). (Ed).

Teaching and learning in the early years. London: RoutledgeFalmer Taylor \&Francis. 